\title{
Production of $\mathrm{NO}$ and $\mathrm{N}_{2} \mathrm{O}$ by Pure Cultures of Nitrifying and Denitrifying Bacteria during Changes in Aeration $\dagger$
}

\author{
RONALD A. KESTER, ${ }^{1}$ WIETSE DE BOER, ${ }^{1 *}$ AND HENDRIKUS J. LAANBROEK ${ }^{2}$ \\ Department of Plant-Microorganism Interactions, Centre for Terrestrial Ecology, Netherlands Institute of Ecology, \\ 6666 ZG Heteren, ${ }^{1}$ and Department of Microbial Ecology, Centre for Limnology, Netherlands Institute of Ecology,
} 3631 AC Nieuwersluis, ${ }^{2}$ The Netherlands

Received 12 May 1997/Accepted 7 August 1997

\begin{abstract}
Peak emissions of $\mathrm{NO}$ and $\mathrm{N}_{2} \mathrm{O}$ are often observed after wetting of soil. The reactions to sudden changes in the aeration of cultures of nitrifying and denitrifying bacteria with respect to $\mathrm{NO}$ and $\mathrm{N}_{2} \mathrm{O}$ emissions were compared to obtain more information about the microbiological aspects of peak emissions. In continuous culture, the nitrifier Nitrosomonas europaea and the denitrifiers Alcaligenes eutrophus and Pseudomonas stutzeri were cultured at different levels of aeration ( 80 to $0 \%$ air saturation) and subjected to changes in aeration. The relative production of $\mathrm{NO}$ and $\mathrm{N}_{2} \mathrm{O}$ by $\mathrm{N}$. europaea, as a percentage of the ammonium conversion, increased from 0.87 and $0.17 \%$, respectively, at $80 \%$ air saturation to 2.32 and $0.78 \%$, respectively, at $1 \%$ air saturation. At $0 \%$ air saturation, ammonium oxidation and $\mathrm{N}_{2} \mathrm{O}$ production ceased but NO production was enhanced. Coculturing of $N$. europaea with the nitrite oxidizer Nitrobacter winogradskyi strongly reduced the relative levels of $\mathrm{NO}$ and $\mathrm{N}_{2} \mathrm{O}$ production, probably as an effect of the lowered nitrite concentration. After lowering the aeration, $N$. europaea produced large short-lasting peaks of $\mathrm{NO}$ and $\mathrm{N}_{2} \mathrm{O}$ emissions in the presence but not in the absence of nitrite. $A$. eutrophus and $P$. stutzeri began to denitrify below $1 \%$ air saturation, with the former accumulating nitrite and $\mathrm{N}_{2} \mathrm{O}$ and the latter reducing nitrate almost completely to $\mathrm{N}_{2}$. Transition of $A$. eutrophus and $P$. stutzeri from 80 to $0 \%$ air saturation resulted in transient maxima of denitrification intermediates. Such transient maxima were not observed after transition from 1 to $0 \%$. Reduction of nitrate by $A$. eutrophus continued $48 \mathrm{~h}$ after the onset of the aeration, whereas $\mathrm{N}_{2} \mathrm{O}$ emission by $P$. stutzeri increased for only a short period. It was concluded that only in the presence of nitrite are nitrifiers able to dominate the NO and $\mathrm{N}_{2} \mathrm{O}$ emissions of soils shortly after a rainfall event.
\end{abstract}

Nitrous oxide $\left(\mathrm{N}_{2} \mathrm{O}\right)$ and nitric oxide (NO) are trace gases contributing to the greenhouse effect, ozone depletion of the stratosphere, and photochemical air pollution $(6,20)$. Nitrifying bacteria, specifically the chemolithotrophic ammonia oxidizers, and denitrifying bacteria appear to be the main biological sources of $\mathrm{NO}$ and $\mathrm{N}_{2} \mathrm{O}(11)$. Emission of $\mathrm{NO}$ and $\mathrm{N}_{2} \mathrm{O}$ is highly variable throughout the year, and peak emissions are reported after (artificial) heavy rainfall $(5,7,8,13,14,16)$. Weekly $\mathrm{N}_{2} \mathrm{O}$ emission measurements in an acid oak-beech forest soil revealed that three individual peaks resulted in $63 \%$ of the total annual emission (28). The importance ascribed to nitrification and denitrification in relation to the $\mathrm{NO}$ and $\mathrm{N}_{2} \mathrm{O}$ emissions after wetting varies in the above-cited studies. On the one hand, denitrifying enzyme activity can persist during dry periods $(9,24,25)$ facilitating a rapid response of denitrification upon wetting, and in addition, de novo synthesis of denitrifying enzymes begins within 4 to $8 \mathrm{~h}$ after wetting (24). On the other hand, the activity of nitrifying organisms has also been reported to result in $\mathrm{NO}$ and $\mathrm{N}_{2} \mathrm{O}$ peaks shortly after wetting of soil $(8,9,16)$. In soil, the release of nitrifier and denitrifier substrates after wetting may selectively enhance the effect of the rapid decrease of oxygen availability on NO and $\mathrm{N}_{2} \mathrm{O}$ emissions by nitrifiers or denitrifiers. In this study we compared the reaction of nitrifying and denitrifying bacteria to sudden changes in aeration and related the reactions to the peak emissions of $\mathrm{NO}$ and $\mathrm{N}_{2} \mathrm{O}$ observed in soil studies. By

\footnotetext{
* Corresponding author. Mailing address: NIOO-CTO, P.O. Box 40, 6666 ZG Heteren, The Netherlands. Phone: 31-26479311. Fax: 31264723227. E-mail: wdeboer@cto.nioo.knaw.nl.

$\dagger$ Publication no. 2276 of the Netherlands Institute of Ecology, Centre for Terrestrial Ecology, Heteren, The Netherlands.
}

using a continuous culture technique, aeration could be controlled at a constant rate of substrate supply.

\section{MATERIALS AND METHODS}

Organisms. The obligate chemolithotrophic ammonia oxidizer Nitrosomonas europaea ATCC 19718, the facultative chemolithotrophic nitrite oxidizer $\mathrm{Ni}$ trobacter winogradskyi ATCC 14123, and the chemoorganotrophic denitrifiers Pseudomonas stutzeri LMAU P12 and Alcaligenes eutrophus LMD 82.41 were the organisms used in this study. $N$. winogradskyi was used to reduce the nitrite level in one of the N. europaea experiments.

Experimental conditions. Organisms were grown separately in continuous culture (1.2 liter culture volume) (Biostat M; Braun, Melsungen, Germany) except for $N$. winogradskyi, which was cocultured with $N$. europaea. The dilution rate was set at $0.030 \mathrm{~h}^{-1}, 0.023 \mathrm{~h}^{-1}$, or $0.083 \mathrm{~h}^{-1}$ for the $N$. europaea cultures, the $N$. europaea and $N$. winogradskyi mixed culture, or the denitrifier cultures, respectively. The experiments were performed in duplicate except for the $N$. europaea and $N$. winogradskyi mixed culture.

The medium for nitrifiers was as described by Laanbroek and Gerards (19), as this medium prevents wallgrowth which is commonly found with mineral media. The medium contained $5 \mathrm{mM}\left(\mathrm{NH}_{4}\right)_{2} \mathrm{SO}_{4}, 10 \mathrm{mM} \mathrm{NaCl}, 1 \mathrm{mM} \mathrm{KH}_{2} \mathrm{PO}_{4}, 0.75$ $\mathrm{mM} \mathrm{CaCl}_{2}, 0.2 \mathrm{mM} \mathrm{MgSO}_{4}, 5 \mathrm{mM}$ sodium pyruvate, $0.15 \%$ (wt/vol) yeast extract (Difco, Detroit, Mich.), 0.15\% (wt/vol) special peptone (Oxoid, Basingstoke, United Kingdom), and $0.1 \%$ (vol/vol) trace element solution (described by Verhagen and Laanbroek [30]). Denitrifiers were cultured in acetate-limited medium which contained $6 \mathrm{mM}$ potassium acetate, $5 \mathrm{mM} \mathrm{NH}_{4} \mathrm{NO}_{3}, 10 \mathrm{mM} \mathrm{NaNO}_{3}$, $1 \mathrm{mM} \mathrm{KH}_{2} \mathrm{PO}_{4}, 0.2 \mathrm{mM} \mathrm{CaCl}_{2}, 1 \mathrm{mM} \mathrm{MgSO}_{4}$, and $0.1 \%$ (vol/vol) trace element solution.

Gas was sparged through the culture and allowed to escape through an exhaust in the top lid of the culture vessel. The level of air saturation and the gas-sparging rate were controlled by a gas flow ratio controller (type B210; Braun). The unit consisted of an air and a nitrogen mass flow controller and was coupled to an oxygen electrode (Ingold, Frankfurt, Germany) in the culture vessel. The gassparging rates (around 0.15 liter $\mathrm{min}^{-1}$ ) were always monitored when gas samples were taken and did not change during transient state. $\mathrm{pH}$ was maintained automatically at 7.5 with $0.5 \mathrm{M} \mathrm{HCl}$ and $5 \%$ (wt/vol) $\mathrm{Na}_{2} \mathrm{CO}_{3}$ for the nitrifiers and $0.5 \mathrm{M} \mathrm{HCl}$ and $0.5 \mathrm{M} \mathrm{NaOH}$ for the denitrifiers. Temperature was kept at $25^{\circ} \mathrm{C}$, and the medium was stirred at $400 \mathrm{rpm}$.

$N$. europaea was successively cultured at $80\left(210 \mu \mathrm{M} \mathrm{O}_{2}\right), 50,20,10,5,1,0,80$, and $0 \%$ air saturation. Except for the $0 \%$ air saturation level, steady-state 
conditions were reached at every air saturation level. At the transition to $0 \%$ air saturation, the dilution of the culture by fresh medium was stopped to prevent washout of $N$. europaea. After 3 days at $0 \%$ air saturation, the air saturation level was set at $80 \%$ and the dilution was resumed after the culture started to grow again. The $N$. europaea and $N$. winogradskyi mixed culture was successively grown to steady state at 80,10 , and $5 \%$ air saturation. Steady state was not reached at $1 \%$ air saturation. $P$. stutzeri and $A$. eutrophus were successively grown to steady state at $80,10,5,1,0,80$, and $0 \%$ air saturation.

Samples were taken almost daily to monitor acetate, ammonium, nitrate, and nitrite concentrations; optical density and $\mathrm{pH}$ of the culture medium; and the NO and $\mathrm{N}_{2} \mathrm{O}$ concentrations of the headspace gas. Headspace gas was sampled aseptically through a Teflon-coated rubber septum. Steady state was usually reached after five volume changes after which the above-mentioned parameters remained constant. At steady state, samples for protein content (only A. eutrophus and $P$. stutzeri) were taken, cell numbers were determined, and the culture was checked for contamination in addition to the routinely measured parameters. After transition to another air saturation level, the $\mathrm{NO}$ and $\mathrm{N}_{2} \mathrm{O}$ concentrations in the headspace gas were monitored.

Analytical procedures. Ammonium and nitrate concentrations were determined in the supernatant $(15 \mathrm{~min}$ at $15,000 \times \mathrm{g})$ of samples stored at $-20^{\circ} \mathrm{C}$ by using a Traacs 800 autoanalyzer (Technicon Instruments Corp., Tarrytown, N.Y.). Directly after sampling, the nitrite concentration was determined colometrically (Griess-Ilosvay reaction) at $540 \mathrm{~nm}$ with a spectrophotometer. The optical density was measured spectrophotometrically at $660 \mathrm{~nm}$. Acetate concentrations were measured with a gas chromatograph (HRGC Mega 2 Series; Fisons Instruments, Milan, Italy) containing a formic acid-saturated Chromosorb 101 column at $180^{\circ} \mathrm{C}$ and a flame ionization detector. Cell numbers were counted microscopically in samples stored on ice by using a Bürker-Türk counting chamber on the day of sampling. Tryptone soy broth (1\% [wt/vol]; Oxoid) agar plates were used to check for contamination. The protein contents of $\mathrm{NaOH}$-boiled cells were determined by Lowry's method with bovine serum albumin (Sigma, St. Louis, Mo.) as standard.

$\mathrm{N}_{2} \mathrm{O}$ concentrations in the headspace gas were measured with a gas chromatograph (GC 6000; Carlo Erba, Milan, Italy) equipped with an electron capture detector. Gases were separated on a Hayesep Q column operated at $80^{\circ} \mathrm{C}$ with helium as carrier gas. A soda lime precolumn was used to absorb carbon dioxide. $\mathrm{N}_{2} \mathrm{O}$ (48 ppm [vol]) in nitrogen standard gas (HoekLoos, Dieren, The Netherlands) was used to calibrate the electron capture detector. NO was detected with a $\mathrm{NO}_{x}$ analyzer (Model 42S; Thermo Environmental Instruments Inc., Franklin Mass.) adapted with a sample-mixing unit for small-volume samples (17). Chemically produced NO was used to make standards (by a modification of the method of Goretski et al. [15]). NO was generated by quantitative reduction of nitrite in anoxic vials containing $12 \mathrm{mM}$ potassium iodide in $0.87 \mathrm{M}$ acetic acid. The concentration of NO in the headspace of the vials was calculated by using the Bunsen absorption coefficient (27).

Statistical procedures. Statistical differences were determined by one-way analyses of variance combined with Tukey tests $(P<0.05)$ by using the Statistix 4.0 software package (Analytical Software, St. Paul, Minn.).

\section{RESULTS}

Nitrification. The steady-state ammonium and nitrite concentrations were between 1 and $2 \mathrm{mM}$ and between 7.8 and 8.8 $\mathrm{mM}$, respectively, in the $N$. europaea cultures at $80,50,20,10$, and $5 \%$ air saturation. At $1 \%$ air saturation, the ammonium concentration increased to $2.65 \mathrm{mM}$ and the nitrite concentration decreased to $7.34 \mathrm{mM}$. The effects of aeration on the ammonium and nitrite concentrations, however, were not significant. Cell numbers at steady state, on average $1.99 \times 10^{8}$ cells $\mathrm{ml}^{-1}$ (standard error, $0.42 \times 10^{8}$ ), were not significantly influenced by aeration. The fraction of ammonium converted into NO increased with the decreasing air saturation level from below $1 \%$ at $80 \%$ air saturation to $2.3 \%$ at $1 \%$ air saturation (Table 1). At $0 \%$ air saturation and a dilution rate of $0, \mathrm{NO}$ was the single nitrogen oxide released by the culture (data not shown). The fraction of $\mathrm{N}_{2} \mathrm{O}$ was lower than the fraction of $\mathrm{NO}$ at every level of air saturation. The relative $\mathrm{N}_{2} \mathrm{O}$ emission from the cultures was around $0.15 \%$ in the range of 80 to $5 \%$ air saturation but increased considerably at $1 \%$ air saturation. At $0 \%$ air saturation (culture dilution rate, 0 ) the $\mathrm{N}_{2} \mathrm{O}$ emission by the culture stopped (data not shown).

The nitrite concentrations in a mixed culture of $N$. europaea and $N$. winogradskyi were below $0.1 \mathrm{mM}$ at steady state at 80 , 10 , and $5 \%$ air saturation. At $1 \%$ air saturation, steady state of the mixed culture was not reached, probably due to washout of
TABLE 1 . The steady-state productions of nitric oxide and nitrous oxide by $N$. europaea in a chemostat $\left(D=0.030 \mathrm{~h}^{-1}\right)$ at different levels of air saturation

\begin{tabular}{clc}
\hline \multirow{2}{*}{$\begin{array}{c}\% \text { Air } \\
\text { saturation }\end{array}$} & \multicolumn{2}{c}{ Mean (SE) \% production $^{a}$} \\
\cline { 2 - 3 } & \multicolumn{1}{c}{ NO } & $\mathrm{N}_{2} \mathrm{O}$ \\
\hline 80 & $0.87 \mathrm{a}(0.16)$ & $0.17 \mathrm{a}(0.02)$ \\
50 & $1.18 \mathrm{ab}(0.11)$ & $0.17 \mathrm{a}(0.04)$ \\
20 & $1.35 \mathrm{ab}(0.21)$ & $0.13 \mathrm{a}(0.01)$ \\
10 & $1.59 \mathrm{ab}(0.39)$ & $0.16 \mathrm{a}(0.16)$ \\
5 & $1.42 \mathrm{ab}(0.08)$ & $0.15 \mathrm{a}(0.01)$ \\
1 & $2.32 \mathrm{~b}(0.13)$ & $0.78 \mathrm{~b}(0.19)$ \\
\hline
\end{tabular}

${ }^{a}$ The productions of nitric oxide and nitrous oxide were calculated as mean percentages of the total amount of converted ammonium for two individual continuous cultures. Within a column, nonsignificant differences are marked with the same letter (Tukey test, $P<0.05$ ).

$N$. winogradskyi. The ammonium concentrations in the mixed culture were more or less the same as the concentrations observed in the pure cultures of $N$. europaea. The fraction of NO was below $0.2 \%$ at every air saturation level tested, and the fraction of $\mathrm{N}_{2} \mathrm{O}$ was below $0.1 \%$ (Table 2). Washout of $N$. winogradskyi at $1 \%$ air saturation resulted in increased emissions of $\mathrm{NO}$ and $\mathrm{N}_{2} \mathrm{O}$. Nonbiological $\mathrm{NO}$ and $\mathrm{N}_{2} \mathrm{O}$ production, tested in aseptic growth medium containing $10 \mathrm{mM}$ nitrite instead of ammonium, was insignificant above $\mathrm{pH} 6.5$ (data not shown).

The $\mathrm{NO}$ and $\mathrm{N}_{2} \mathrm{O}$ emissions for the $N$. europaea cultures were monitored directly after the air saturation level was lowered. Transitions from 10 to $5 \%$ and from 5 to $1 \%$ air saturation resulted in increased $\mathrm{NO}$ and $\mathrm{N}_{2} \mathrm{O}$ fluxes (Fig. $1 \mathrm{~A}$ and $\mathrm{B}$ ). Increased $\mathrm{NO}$ and $\mathrm{N}_{2} \mathrm{O}$ fluxes were immediately visible upon the shift in air saturation with maxima after approximately 15 min, which subsequently subsided over periods of $1 \mathrm{~h}$ and $4 \mathrm{~h}$, respectively. Transition from 1 to $0 \%$ air saturation (dilution rate, 0 ) enhanced the $\mathrm{NO}$ flux but not the $\mathrm{N}_{2} \mathrm{O}$ flux (Fig. 1C). The enhanced NO flux continued throughout the 3-day anoxic period (data not shown), in contrast to the short-lasting peaks after the 10 to $5 \%$ and 5 to $1 \%$ transitions. The switch from 80 to $0 \%$ air saturation (dilution rate, 0 ) resulted in $\mathrm{NO}$ and $\mathrm{N}_{2} \mathrm{O}$ peaks during the first hour and an increased level of the NO flux later on, whereas the $\mathrm{N}_{2} \mathrm{O}$ flux stopped after $2 \mathrm{~h}$ (Fig. 1D). In the $N$. europaea cultures, transition from 20 to $10 \%$ air saturation was followed by small $\mathrm{NO}$ and $\mathrm{N}_{2} \mathrm{O}$ peaks, and after transitions from 80 to $50 \%$ and 50 to $20 \%$ air saturation, no $\mathrm{NO}$ and $\mathrm{N}_{2} \mathrm{O}$ peaks were detected (data not shown).

Like the $N$. europaea pure cultures, a mixed culture of $N$. europaea and $N$. winogradskyi was subjected to changes in air saturation level. Transition from 80 to $10 \%$ resulted in a $\mathrm{N}_{2} \mathrm{O}$ peak (Fig. 2A) which was, however, very small compared to the peaks found in the $N$. europaea pure cultures. No peaks were

TABLE 2. The steady-state productions of nitric oxide and nitrous oxide by a $N$. europaea and $N$. winogradskyi mixed culture in a chemostat $\left(D=0.023 \mathrm{~h}^{-1}\right)$ at different levels of air saturation

\begin{tabular}{ccc}
\hline \multirow{2}{*}{$\begin{array}{c}\text { Air } \\
\text { saturation }\end{array}$} & \multicolumn{2}{c}{$\%$ Production $^{a}$} \\
\cline { 2 - 3 } & $\mathrm{NO}$ & $\mathrm{N}_{2} \mathrm{O}$ \\
\hline 80 & 0.14 & 0.08 \\
10 & 0.18 & 0.04 \\
5 & 0.20 & 0.06
\end{tabular}

${ }^{a}$ The productions of nitric oxide and nitrous oxide were calculated as percentages of the total amount of converted ammonium. 

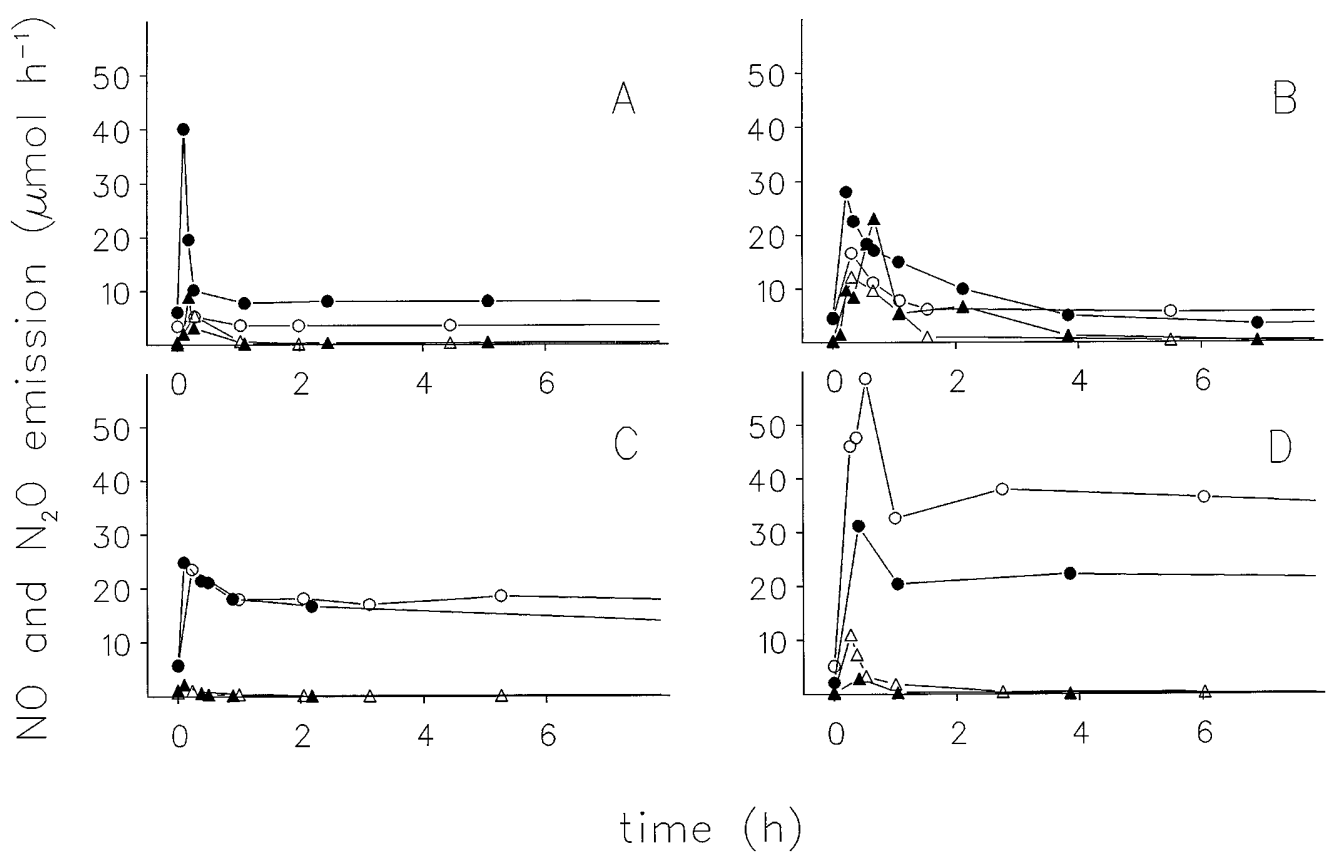

FIG. 1. Emission of nitric oxide and nitrous oxide by two continuous cultures of $N$. europaea during transient state after a change in the level of air saturation. At time zero air saturation was switched from 10 to $5 \%$ (A), 5 to $1 \%$ (B), 1 to $0 \%$ (C), and 80 to $0 \%$ (D). At $0 \%$ air saturation the dilution rate was 0 . Circles and triangles represent nitric oxide and nitrous oxide emissions, respectively. Open and closed symbols represent the nitric oxide and nitrous oxide emissions of the two individual continuous cultures.

detected after transition from 10 to $5 \%$ air saturation (Fig. 2B), although the $\mathrm{N}_{2} \mathrm{O}$ flux of the mixed culture showed some increase $4 \mathrm{~h}$ after the transition. A small and short-lasting $\mathrm{N}_{2} \mathrm{O}$ peak was found after transition from 5 to $1 \%$ air saturation, which coincided with a small dip in the NO flux of the mixed culture (Fig. 2C). As reported above, N. winogradskyi washed out at $1 \%$ air saturation, which coincided with the slow increase of the $\mathrm{NO}$ and $\mathrm{N}_{2} \mathrm{O}$ fluxes from that mixed culture.

Denitrification. At steady state, the acetate concentrations in the A. eutrophus cultures were below the detection limit (less than $0.1 \mathrm{mM}$ acetate) and between 0.66 and $0.78 \mathrm{mM}$ for the $P$. stutzeri cultures. The protein yield of the $A$. eutrophus cultures
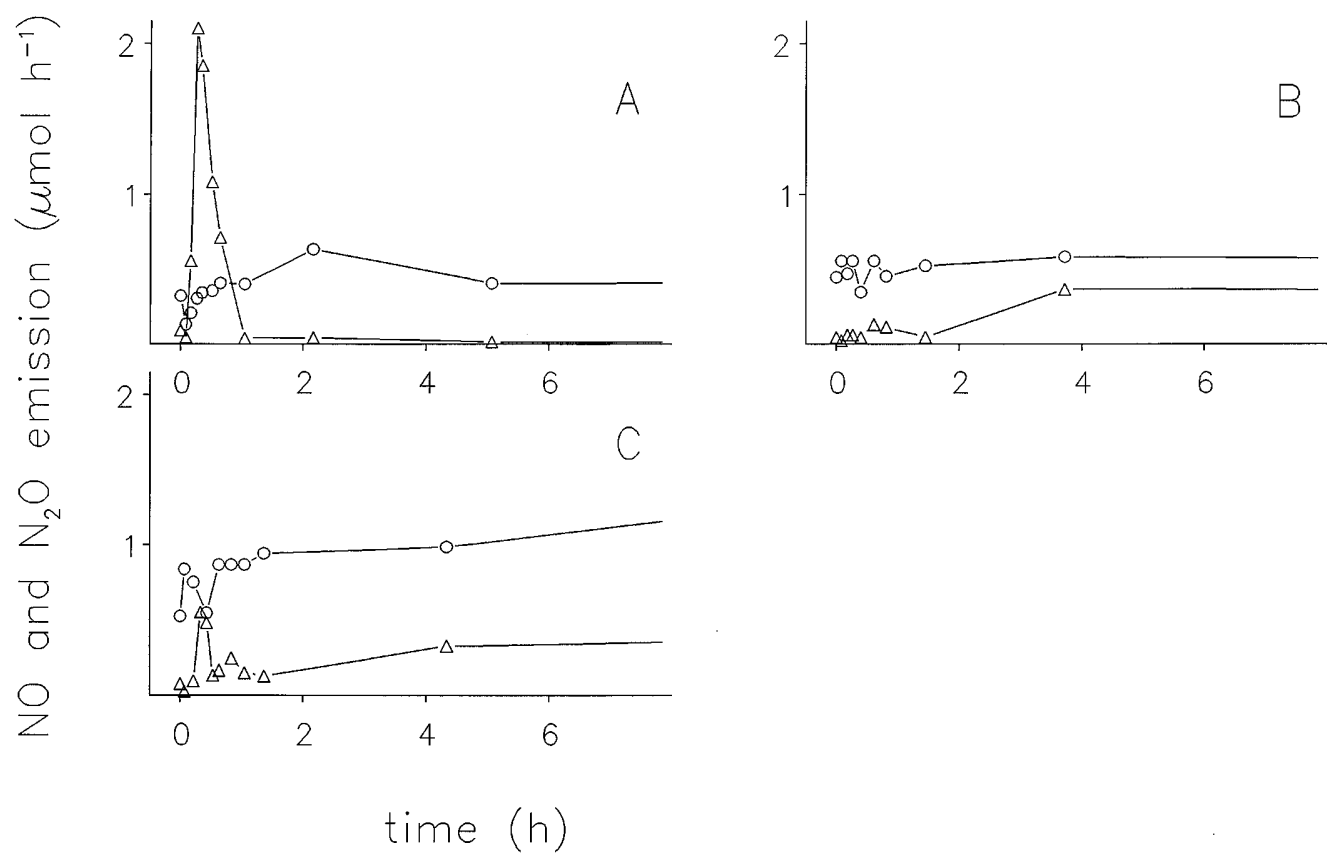

time (h)

FIG. 2. Emission of nitric oxide and nitrous oxide by a continuous culture of $N$. europaea and $N$. winogradskyi during transient state after a change in the level of air saturation. At time zero air saturation was switched from 80 to $10 \%$ (A), 10 to $5 \%$ (B), and 5 to $1 \%$ (C). Circles and triangles represent nitric oxide and nitrous oxide emissions, respectively. 
TABLE 3. The steady-state productions of nitrite, nitric oxide, and nitrous oxide by $A$. eutrophus and $P$. stutzeri in acetate-limited chemostats $\left(\mathrm{D}=0.083 \mathrm{~h}^{-1}\right)$ at different levels of air saturation

\begin{tabular}{lcccc}
\hline \multirow{2}{*}{ Strain } & $\begin{array}{c}\text { \% Air } \\
\text { saturation }\end{array}$ & \multicolumn{3}{c}{$\begin{array}{c}\text { Mean (SE) production }\left(\mu \mathrm{mol} \mathrm{liter}^{-1}\right. \\
\left.\text { of culture } \mathrm{h}^{-1}\right)^{a}\end{array}$} \\
\cline { 3 - 5 } & & \multicolumn{1}{c}{$\mathrm{NO}_{2}^{-}$} & $\mathrm{NO}$ & $\mathrm{N}_{2} \mathrm{O}$ \\
\hline A. eutrophus & 80 & $5.5(3.8) \mathrm{a}$ & $0.006(0.006) \mathrm{a}$ & $0.07(0.04) \mathrm{a}$ \\
& 10 & $4.3(2.6) \mathrm{a}$ & $0.006(0.002) \mathrm{a}$ & $0.02(0.00) \mathrm{a}$ \\
& 5 & $19.0(9.6) \mathrm{a}$ & $0.004(0.004) \mathrm{a}$ & $0.23(0.02) \mathrm{a}$ \\
& 1 & $41.5(11.6) \mathrm{a}$ & $0.006(0.002) \mathrm{a}$ & $0.21(0.02) \mathrm{a}$ \\
& 0 & $588.9(55.6) \mathrm{b}$ & $2.062(0.391) \mathrm{b}$ & $79.99(7.78) \mathrm{b}$ \\
& & & & \\
& 80 & $0.4(0.4) \mathrm{a}$ & $0.000(0.000) \mathrm{a}$ & $0.06(0.06) \mathrm{a}$ \\
& 10 & $10.1(10.1) \mathrm{a}$ & $0.132(0.132) \mathrm{a}$ & $0.28(0.20) \mathrm{ab}$ \\
& 5 & $5.3(4.4) \mathrm{a}$ & $0.136(0.127) \mathrm{a}$ & $0.27(0.15) \mathrm{ab}$ \\
& 1 & $3.1(3.1) \mathrm{a}$ & $0.140(0.114) \mathrm{a}$ & $0.31(0.28) \mathrm{ab}$ \\
& 0 & $18.9(0.4) \mathrm{b}$ & $0.702(0.009) \mathrm{b}$ & $1.29(0.22) \mathrm{b}$ \\
\hline
\end{tabular}

${ }^{a}$ Data are mean percent production amounts for two individual continuous cultures for each species. Within a column (per species), nonsignificant differences are marked with the same letter (Tukey test, $P<0.05$ ).

decreased from $13.9 \mathrm{~g}$ at $80 \%$ air saturation to $7.63 \mathrm{~g}$ of protein per mol of acetate at $0 \%$ air saturation. The protein yield of $P$. stutzeri was lower than the yield of $A$. eutrophus and ranged between 9.8 and $7.1 \mathrm{~g}$ of protein per mol of acetate at 80 and $0 \%$ air saturation, respectively. Both cultures were acetate limited as was shown by elevations in cell number, optical density, and protein content upon doubling the acetate concentration in the growth medium (data not shown).

Anoxity strongly enhanced the production of nitrite, NO, and $\mathrm{N}_{2} \mathrm{O}$ by $A$. eutrophus (Table 3 ). Between 80 and $1 \%$ air saturation, there were no significant effects of the level of air saturation on the production of nitrite, $\mathrm{NO}$, and $\mathrm{N}_{2} \mathrm{O}$. The effects of the air saturation level on the production of nitrite, $\mathrm{NO}$, and $\mathrm{N}_{2} \mathrm{O}$ by $P$. stutzeri were similar to the effects found with $A$. eutrophus but less pronounced. The nitrite and $\mathrm{N}_{2} \mathrm{O}$ production by $A$. eutrophus at anoxia was significantly higher than that of $P$. stutzeri. As calculated from the nitrogen balance under acetate limitation, $P$. stutzeri tended to reduce nitrate completely to $\mathrm{N}_{2}$ (96\% of reduced nitrate), whereas $A$. eutrophus accumulated the intermediates nitrite and $\mathrm{N}_{2} \mathrm{O}$ besides $\mathrm{N}_{2}$ (56, 15, and $29 \%$ of reduced nitrate, respectively).

The effects of changed aeration on $\mathrm{NO}$ and $\mathrm{N}_{2} \mathrm{O}$ emissions and nitrite accumulation by $A$. eutrophus and $P$. stutzeri are shown in Fig. 3 for one replicate. The patterns of $\mathrm{NO}$ and $\mathrm{N}_{2} \mathrm{O}$ emission and nitrite accumulation were the same between replicates. For both denitrifiers, it took less time to reach steady state after the 1 to $0 \%$ air saturation transition than after the 80 to $0 \%$ air saturation transition. Distinct transient maxima of $\mathrm{NO}$ and nitrite were observed after the 80 to $0 \%$ air saturation transition.

$\mathrm{NO}$ and $\mathrm{N}_{2} \mathrm{O}$ emissions ceased almost immediately when oxygen was supplied to the anoxic $A$. eutrophus culture (Fig. 3C), whereas $\mathrm{N}_{2} \mathrm{O}$ emission of $P$. stutzeri was shortly but strongly enhanced under these conditions (Fig. 3F). The nitrite concentration in the $A$. eutrophus culture decreased gradually. Calculated from the dilution rate, substantial residual nitrite production continued for up to $48 \mathrm{~h}$ after the aeration switch. In the $P$. stutzeri culture, the rate of decrease of the nitrite concentration after the 0 to $80 \%$ air saturation transition indicated some residual nitrite production for up to $29 \mathrm{~h}$. Tran-

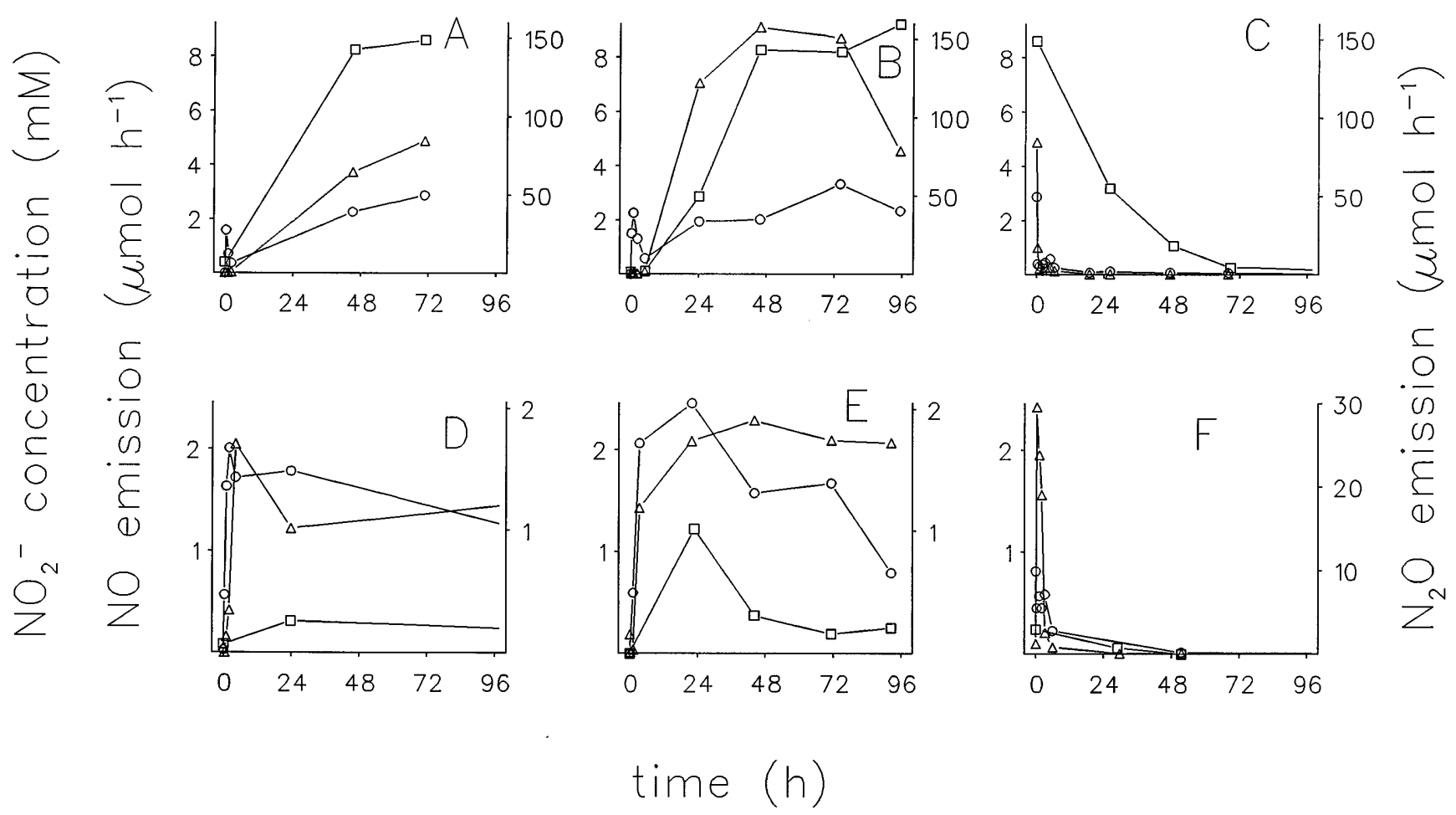

FIG. 3. Emission of nitric oxide and nitrous oxide and the accumulation of nitrite in representative continuous cultures of $A$. eutrophus (A to C) and $P$. stutzeri (D to $\mathrm{F}$ ) during transient state after a change in the level of air saturation. At time zero air saturation was switched from 1 to $0 \%$ (A and $\mathrm{D}$ ), 80 to $0 \%$ (B and $\mathrm{E}$ ), and 0 to $80 \%$ (C and F). Circles, triangles, and squares represent nitric oxide emission (left axis), nitrous oxide emission (right axis), and nitrite accumulation (left axis), respectively. 
sitions from 80 to $10 \%, 10$ to $5 \%$ and 5 to $1 \%$ air saturation did not influence the emission of $\mathrm{NO}$ and $\mathrm{N}_{2} \mathrm{O}$ by either denitrifier (data not shown).

\section{DISCUSSION}

Nitrification. Down to $1 \%$ air saturation, oxygen concentration did not significantly influence the growth characteristics of $N$. europaea, which is in accordance with the results of Goreau et al. (14). The relatively high amounts of ammonium in the culture medium at steady state are explained by the high $K_{m}$ for ammonia of $N$. europaea (19). The fraction of nitrogen converted to $\mathrm{NO}$ and $\mathrm{N}_{2} \mathrm{O}$ increases with a decreasing air saturation level. Although the fractions of $\mathrm{NO}$ and $\mathrm{N}_{2} \mathrm{O}$ at oxygen-poor steady states are low compared to the fractions found in some other studies (e.g., 19\% N loss [26] and nearly $10 \% \mathrm{~N}_{2} \mathrm{O}-\mathrm{N}$ [14]), they are in good agreement with the results of Remde and Conrad (23), 1.4 to $2.7 \% \mathrm{NO}$ and 0.1 to $3.9 \%$ $\mathrm{N}_{2} \mathrm{O}$ (depending on cell density), and Anderson et al. (1), $2.6 \%$ $\mathrm{NO}$ and $1 \% \mathrm{~N}_{2} \mathrm{O}$. The discrepancies with the high fractions of $\mathrm{NO}$ and $\mathrm{N}_{2} \mathrm{O}$ reported in other studies might be due to dissimilar behaviors of the different strains of $N$. europaea used or to the use of different incubation systems (i.e., batch versus continuous culture). The strain used in this study was the same as that used by Anderson et al. (1).

Anderson et al. (1) found an optimum for $\mathrm{NO}$ and $\mathrm{N}_{2} \mathrm{O}$ production by $N$. europaea between $0.2 \mathrm{kPa}$ and $0.4 \mathrm{kPa} \mathrm{pO}_{2}$ (approximately 1 and 2\% air saturation, respectively) at low nitrite concentrations. The authors stated that at high nitrite concentrations the influence of $\mathrm{pO}_{2}$ is limited, perhaps because of competition between the terminal oxidase and nitrite reductase for electrons. Reduction of nitrite is thought to be the prime source of $\mathrm{NO}$ and $\mathrm{N}_{2} \mathrm{O}$ emissions by nitrifiers. The weak enhancement of $\mathrm{NO}$ and $\mathrm{N}_{2} \mathrm{O}$ production at reduced oxygen concentrations in the N. europaea cultures in our study is probably also related to the high nitrite concentrations.

The strongly reduced $\mathrm{NO}$ and $\mathrm{N}_{2} \mathrm{O}$ emissions by the $N$. europaea and $N$. winogradskyi mixed culture was probably due to the low nitrite concentration in the mixed culture. It is possible that NO consumption by $N$. winogradskyi may have occurred as well, as reported by Freitag and Bock (12).

The peak emissions of $\mathrm{NO}$ and $\mathrm{N}_{2} \mathrm{O}$ after changes in aeration have, to the best of our knowledge, never been reported before for $N$. europaea cultures. However, Bock et al. (3) described a large loss of nitrogen on the same day for a $N$. europaea culture whose oxygen concentration was decreased from 0.4 to $0.2 \mathrm{mg} / \mathrm{liter}$, but this was not recognized as a peak emission by the authors. The switch in oxygen supply in our study apparently disturbed the metabolism of $N$. europaea at 10 and $5 \%$ air saturation, resulting in the short-lasting peaks of $\mathrm{NO}$ and $\mathrm{N}_{2} \mathrm{O}$ emission. These peaks were not observed in the $N$. europaea and $N$. winogradskyi mixed culture, suggesting again that nitrite concentration is an important factor for the production of $\mathrm{NO}$ and $\mathrm{N}_{2} \mathrm{O}$. The high gas-sparging rate in the culture makes immediate NO utilization by $N$. winogradskyi an unlikely explanation for the decreased NO production.

The patterns of $\mathrm{NO}$ and $\mathrm{N}_{2} \mathrm{O}$ emission by $N$. europaea after transition from 80 to $0 \%$ air saturation resemble a combination of the 5 to $1 \%$ and 1 to $0 \%$ patterns. This is probably the result of the relatively slow decrease of the oxygen concentration (it took 9 min to go from 80 to $0 \%$ air saturation). In contrast to the nitrite reductase of $N$. europaea studied by Miller and Nicholas (21), which was only induced at low oxygen tension, our results suggest that nitrite reductase must have been present in large amounts at $80 \%$ air saturation in order to allow for peaks in $\mathrm{NO}$ and $\mathrm{N}_{2} \mathrm{O}$ immediately after transition.
The mechanism of $\mathrm{NO}$ and $\mathrm{N}_{2} \mathrm{O}$ peak production by $N$. europaea and the role of nitrite has yet to be elucidated.

Denitrification. A. eutrophus and $P$. stutzeri cultures started to denitrify below $1 \%$ air saturation. In the $A$. eutrophus cultures, transition from 1 to $0 \%$ air saturation resulted in gradual increases of $\mathrm{NO}$ and $\mathrm{N}_{2} \mathrm{O}$, whereas a transient $\mathrm{N}_{2} \mathrm{O}$ maximum was observed after the transition from 80 to $0 \%$ air saturation. In addition, it took more time to reach steady state in the latter case, suggesting that the $\mathrm{N}$ reductases were already present at $1 \%$ air saturation but not at $80 \%$ air saturation. Measurements of the $\mathrm{N}$ reductase activity of the related Alcaligenes faecalis at different aeration levels support this explanation (22).

In the $P$. stutzeri cultures switched from 1 to $0 \%$ air saturation, steady-state levels of $\mathrm{NO}$ and $\mathrm{N}_{2} \mathrm{O}$ emission and nitrite accumulation were reached within $24 \mathrm{~h}$. After the transition from 80 to $0 \%$ air saturation, transient maxima were observed and it took more time to reach steady-state levels. Körner and Zumft (18) observed elevated expressions of nitrate reductase, nitrite reductase, and nitrous oxide reductase (nitric oxide reductase was not tested) at $17 \%$ air saturation and below in $P$. stutzeri. The results in the present study indicate that at $1 \%$ air saturation $P$. stutzeri cells contained the complete denitrifying pathway as denitrification commenced immediately and with relatively low transient accumulation of intermediates. The unexpected rapid increases of $\mathrm{NO}$ and $\mathrm{N}_{2} \mathrm{O}$ after transition from 80 to $0 \%$ air saturation suggests that $P$. stutzeri cells are able to induce these reductases within $1 \mathrm{~h}$. Baumann et al. (2) showed that Paracoccus denitrificans expressed enhanced levels of NaR and NoS mRNA immediately after an oxic to anoxic transition, and they detected denitrification metabolites after $30 \mathrm{~min}$.

Nitrifier versus denitrifier $\mathrm{NO}$ and $\mathrm{N}_{2} \mathrm{O}$ emissions. Although it is difficult to directly relate quantitative $\mathrm{NO}$ and $\mathrm{N}_{2} \mathrm{O}$ emission data from simple chemostat systems to complex natural environments, some of the key underlying mechanisms may hold true. With the organisms used in this study, it was confirmed that denitrifier $\mathrm{NO}$ and $\mathrm{N}_{2} \mathrm{O}$ emissions are restricted to anoxic environments, whereas nitrifier $\mathrm{NO}$ and $\mathrm{N}_{2} \mathrm{O}$ emissions are highest at oxygen-poor sites and $\mathrm{N}_{2} \mathrm{O}$ emission is absent at $0 \%$ oxygen. Significant NO emission by $N$. europaea was found at anoxic conditions and probably requires nitrite and an endogenous substrate or simple organic substrates.

As conditions in soil constantly change, a steady-state-like situation is rarely obtained. Therefore, the dynamics of NO and $\mathrm{N}_{2} \mathrm{O}$ emission by nitrifiers and denitrifiers in reaction to changes in the microenvironment of these organisms are probably at least as important as steady-state emission data. The results of this study suggest that rapid decreases in oxygen availability cause larger emissions of $\mathrm{NO}$ and $\mathrm{N}_{2} \mathrm{O}$ by denitrifiers than do slow decreases. A slow decrease of oxygen availability allows time for adjustment in the activity of the $\mathrm{N}$ reductases in the denitrifying pathway. The persistence of denitrifying enzyme activity during drought has not been addressed in this study. Nitrite reductase and nitrous oxide reductase are, however, less persistent than nitrate reductase (10), which suggests that the "old" denitrifying enzyme pool enhances accumulation and emission of denitrification intermediates immediately after rapid decrease in oxygen availability.

This study shows that ammonium-oxidizing bacteria may be able to dominate the emission of $\mathrm{N}_{2} \mathrm{O}$, and especially that of NO, shortly after decreased oxygen availability. Furthermore, substantial NO emission persists under anoxic conditions. The presence of nitrite seems to play an important role in NO and $\mathrm{N}_{2} \mathrm{O}$ emissions. Nitrite accumulation in soil is rare, with occasional exceptions such as after the application of alkalinehydrolyzing ammonium fertilizers or at low moisture content, 
and is associated with alkaline conditions $(4,29)$. Davidson et al. (8) reported accumulation of nitrite in a dry deciduous forest soil and observed pulses of nitrifier $\mathrm{NO}$ and $\mathrm{N}_{2} \mathrm{O}$ emissions after wetting of neutral soils, whereas Hutchinson et al. (16) observed NO peaks after wetting alkaline soil. Low nitrite concentrations of the bulk soil were detected in the latter case, but drying may concentrate nitrite in thin waterfilms and contribute to nitrite accumulation in microsites (11). $\mathrm{NO}$ and $\mathrm{N}_{2} \mathrm{O}$ peaks described in this study fit well with the above-mentioned field observations. Accumulation of nitrite in neutral to acidic soils is less likely in temperate regions, except shortly after fertilization, and $\mathrm{NO}$ and $\mathrm{N}_{2} \mathrm{O}$ peaks after rainfall events are therefore probably dominated by denitrification emission. In agricultural soils, the type of ammonium fertilizer, i.e., acid or alkaline hydrolyzing, may influence the magnitude of the nitrifier $\mathrm{NO}$ and $\mathrm{N}_{2} \mathrm{O}$ peaks after rainfall events.

\section{ACKNOWLEDGMENTS}

We thank Saskia Gerards for supplying the nitrifier cultures and Paul Bodelier, George Kowalchuk, and Jan Woldendorp for critical reading of the manuscript.

\section{REFERENCES}

1. Anderson, I. C., M. Poth, J. Homstead, and D. Burdige. 1993. A comparison of $\mathrm{NO}$ and $\mathrm{N}_{2} \mathrm{O}$ production by the autotrophic nitrifier Nitrosomonas europaea and the heterotrophic nitrifier Alcaligenes faecalis. Appl. Environ. Microbiol. 59:3525-3533.

2. Baumann, B., M. Snozzi, A. J. B. Zehnder, and J. R. van der Meer. 1996. Dynamics of denitrification activity of Paracoccus denitrificans in continuous culture during aerobic-anaerobic changes. J. Bacteriol. 178:4367-4374.

3. Bock, E., L. Schmidt, R. Stüven, and D. Zwart. 1995. Nitrogen loss caused by denitrifying Nitrosomonas cells using ammonium or hydrogen as electron donor and nitrite as electron acceptor. Arch. Microbiol. 163:16-20.

4. Chalk, P. M., and C. J. Smith. 1983. Chemodenitrification, p. 65-89. In J. R. Freney and J. R. Simpson (ed.), Gaseous loss of nitrogen. Nijhoff, The Hague, The Netherlands.

5. Corre, M. D., C. Vankessel, D. J. Pennock, and M. P. Solohub. 1995. Ambient nitrous oxide emissions from different landform complexes as affected by simulated rainfall. Commun. Soil Sci. Plant Anal, 26:2279-2293.

6. Crutzen, P. J. 1981. Atmospheric chemical process of the oxides of nitrogen, including nitrous oxide, p. 17-44. In C. C. Delwiche (ed.), Denitrification, nitrification and atmospheric nitrous oxide. Wiley \& Sons Inc, New York, N.Y.

7. Davidson, E. A. 1992. Sources of nitric oxide and nitrous oxide following wetting of dry soil. Soil Sci. Soc. Am. J. 56:95-102.

8. Davidson, E. A., P. A. Matson, P. M. Vitousek, R. Riley, K. Dunkin, G. Garciamendez, and J. M. Maass. 1993. Processes regulating soil emissions of $\mathrm{NO}$ and $\mathrm{N}_{2} \mathrm{O}$ in a seasonally dry tropical forest. Ecology 74:130-139.

9. Dendooven, L., and J. M. Anderson. 1994. Dynamics of reduction enzymes involved in the denitrification process in pasture soil. Soil Biol. Biochem. 26:1501-1506.

10. Dendooven, L., and J. M. Anderson. 1995. Maintenance of denitrification potential in pasture soil following anaerobic events. Soil Biol. Biochem. 27:1251-1260.
11. Firestone, M. K., and E. A. Davidson. 1989. Microbiological basis of NO and $\mathrm{N}_{2} \mathrm{O}$ production and consumption in soil, p. 7-21. In M. O. Andrea and D. S. Schimel (ed.), Exchange of trace gases between terrestrial ecosystems and the atmosphere. John Wiley \& Sons, Chichester, United Kingdom.

12. Freitag, A., and E. Bock. 1990. Energy conservation in Nitrobacter. FEMS Microbiol. Lett. 66:157-162.

13. Goodroad, L. L., and D. R. Keeney. 1984. Nitrous oxide emission from forest marsh and prairie. J. Environ. Qual. 13:448-452.

14. Goreau, T. J., W. A. Kaplan, S. C. Wofsy, M. B. McElroy, F. W. Valois, and S. W. Watson. 1980. Production of $\mathrm{NO}_{2}{ }^{-}$and $\mathrm{N}_{2} \mathrm{O}$ by nitrifying bacteria at reduced concentrations of oxygen. Appl. Environ. Microbiol. 40:526-532.

15. Goretski, J., O. C. Zafiriou, and T. C. Hollocher. 1990. Steady-state nitric oxide concentrations during denitrification. J. Biol. Chem. 265:11535-11538.

16. Hutchinson, G. L., W. D. Guenzi, and G. P. Livingston. 1993. Soil water controls on aerobic soil emission of gaseous nitrogen oxides. Soil Biol. Biochem. 25:1-9.

17. Kester, R. A., A. G. Wijhuizen, H. Duyts, and H. J. Laanbroek. 1994. Chemiluminescence analysis of nitric oxide in small-volume samples by a modified injection method. Biol. Fertil. Soils 18:260-262.

18. Körner, H., and W. G. Zumft. 1989. Expression of denitrification enzymes in response to dissolved oxygen level and respiratory substrate in continuous culture of Pseudomonas stutzeri. Appl. Environ. Microbiol. 55:1670-1676.

19. Laanbroek, H. J., and S. Gerards. 1993. Competition for limiting amounts of oxygen between Nitrosomonas europaea and Nitrobacter winogradskyi grown in mixed continuous cultures. Arch. Microbiol. 159:453-459.

20. Melillo, J. M., P. A. Steudler, J. D. Aber, and R. D. Bowden. 1989. Atmospheric deposition and nutrient cycling, p. 263-280. In M. O. Andrea and D. S. Schimel (ed.), Exchange of trace gases between terrestrial ecosystems and the atmosphere. John Wiley \& Sons, Chichester, United Kingdom.

21. Miller, D. J., and D. J. D. Nicholas. 1985. Characterization of a soluble cytochrome oxidase/nitrite reductase from Nitrosomonas europaea. J. Gen. Microbiol. 131:2851-2854.

22. Otte, S. A., N. G. Grobben, L. A. Robertson, M. S. M. Jetten, and J. G. Kuenen. 1996. Nitrous oxide production by Alcaligenes faecalis under transient and dynamic aerobic and anaerobic conditions. Appl. Environ. Microbiol. 62:2421-2426.

23. Remde, A., and R. Conrad. 1990. Production of nitric oxide in Nitrosomonas europaea by reduction of nitrite. Arch. Microbiol. 154:187-191.

24. Rudaz, A. O., E. A. Davidson, and M. K. Firestone. 1991. Sources of nitrous oxide production following wetting of dry soil. FEMS Microbiol. Ecol. 85: $117-124$.

25. Smith, M. S., and L. L. Parsons. 1985. Persistence of denitrifying enzyme activity in dried soils. Appl. Environ. Microbiol. 49:316-320.

26. Stüven, R., M. Vollmer, and E. Bock. 1992. The impact of organic matter on nitric oxide formation by Nitrosomonas europaea. Arch. Microbiol. 158:439443.

27. Tiedje, J. M. 1982. Denitrification, p. 1011-1026. In A. L. Page, R. H. Miller and D. R. Keeney (ed.), Methods of soil analysis, part 2. Chemical and microbiological properties. American Society of Agronomy and Soil Science Society of America, Madison, Wis.

28. Tietema, A., W. Bouten, and P. E. Wartenbergh. 1991. Nitrous oxide dynamics in an oak-beech forest ecosystem in the Netherlands. For. Ecol. Manag. 44:53-61.

29. Van Cleemput, A., and L. Baert. 1984. Nitrite: a key compound in N loss processes under acidic conditions? Plant Soil 76:233-241.

30. Verhagen, F. J. M., and H. J. Laanbroek. 1991. Competition for ammonium between nitrifying and heterotrophic bacteria in dual energy-limited chemostats. Appl. Environ. Microbiol. 57:3255-3263. 